\title{
CHERNEL ISTVÁN EMLÉKTÁBLÁJÁNAK AVATÁSA SOPRONBAN
}

\author{
Faragó Sándor \\ Soproni Egyetem, Vadgazdálkodási és Gerinces Állattani Intézet \\ University of Sopron, Institute of Wildlife Management and Vertebrate Zoology \\ H-9400 Sopron, Bajcsy-Zs u. 4., Hungary
}

\begin{abstract}
FARAGÓ S. (2019): INAUGURATION OF ISTVÁN CHERNEL'S PLAQUE IN SOPRON. Hungarian Small Game Bulletin 14: 213-218. http://dx.doi.org/10.17243/mavk.2019.213

On 22nd October 2015, the University of West Hungary dedicated a plaque on the wall of the house at 9 Szt.. György Street in Sopron, to chernelházi ISTVÁN CHERNEL, the Europe-famous researcher of the Hungarian ornithology, at the same time the second leader of the Hungarian Ornithological Centre. ISTVÁN CHERNEL was pursuing his secondary school studies between 1879-1883, at the that time Benedictine Main Secondary School at 9 Szt. György Street. Dr. LÁszló KÁRPÁTI retired director of the Fertö-Hanság National Park gave the inaugural speech. Dr. TAMÁS FODOR, the mayor of the City of Sopron, in the name of the citizens of the town, took over the memorial place.
\end{abstract}

KULCSZAVAK: CHERNEL ISTVÁN, emléktábla, Sopron

KEY WORDS: ISTVÁN CHERNEL, plaque, Sopron

A magyar madártan Európa hírü tudós kutatójának, a Magyar Ornithológiai Központ az alapító HERMAN OTTÓ utáni - második igazgatójának állított emléket a Nyugatmagyarországi Egyetem Sopronban, a Szent György utca 9. számú ház falán 2015. október 22-én avatott emléktáblával (1. ábra).

CHERNEL ISTVÁN ugyanis felsőbb gimnáziumi tanulmányait a Szent György utca 9. alatti egykori Bencés Főgimnáziumban végezte 1879-1883 között. Természetrajz tanára volt a kor elismert ornitológusa FÁSZL ISTVÁN OSB, akinek a Magyar Ornithológusok Szövetsége állított egykoron emléktáblát ugyancsak a gimnázium épület homlokzatán.

Születésének 150. évfordulóján a Nyugat-magyarországi Egyetem és a Roth Gyula Erdészeti és Faipari Szakközépiskola bensőséges ünnepséggel emlékezett meg CHERNEL ISTVÁNRÓL. A nagyszámú közönség Dr. KÁRPÁTI LÁszLÓ, a Fertö-Hanság Nemzeti park ny. igazgatója, c. egyetemi tanár nagy ívü avatóbeszéde után CHERNEL ISTVÁN gimnazistaként, a haza- és a természetszeretetről Sopronban írt verseiből hallgathatott meg egy csokorra valót a Roth Gyula Szakközépiskola diákjainak tolmácsolásában, majd az emléktábla leleplezése és megkoszorúzása után, Dr. FODOR TAMÁs polgármester Sopron megyei jogú város polgársága nevében vette át az emlékhelyet és beszédében méltatta a tudósok és tudomány szerepét a város életében.

2015. október 22 óta a mester - FÁSZL ISTVÁN - és a tanítvány - CHERNEL ISTVÁN emléktáblája közösen hirdeti az egykori gimnázium természettudományos oktatásának nagyszerüségét.

Az emléktáblát készítette és ajándékozta KÁROLYI GYULA soproni kőfaragómester és fia. 


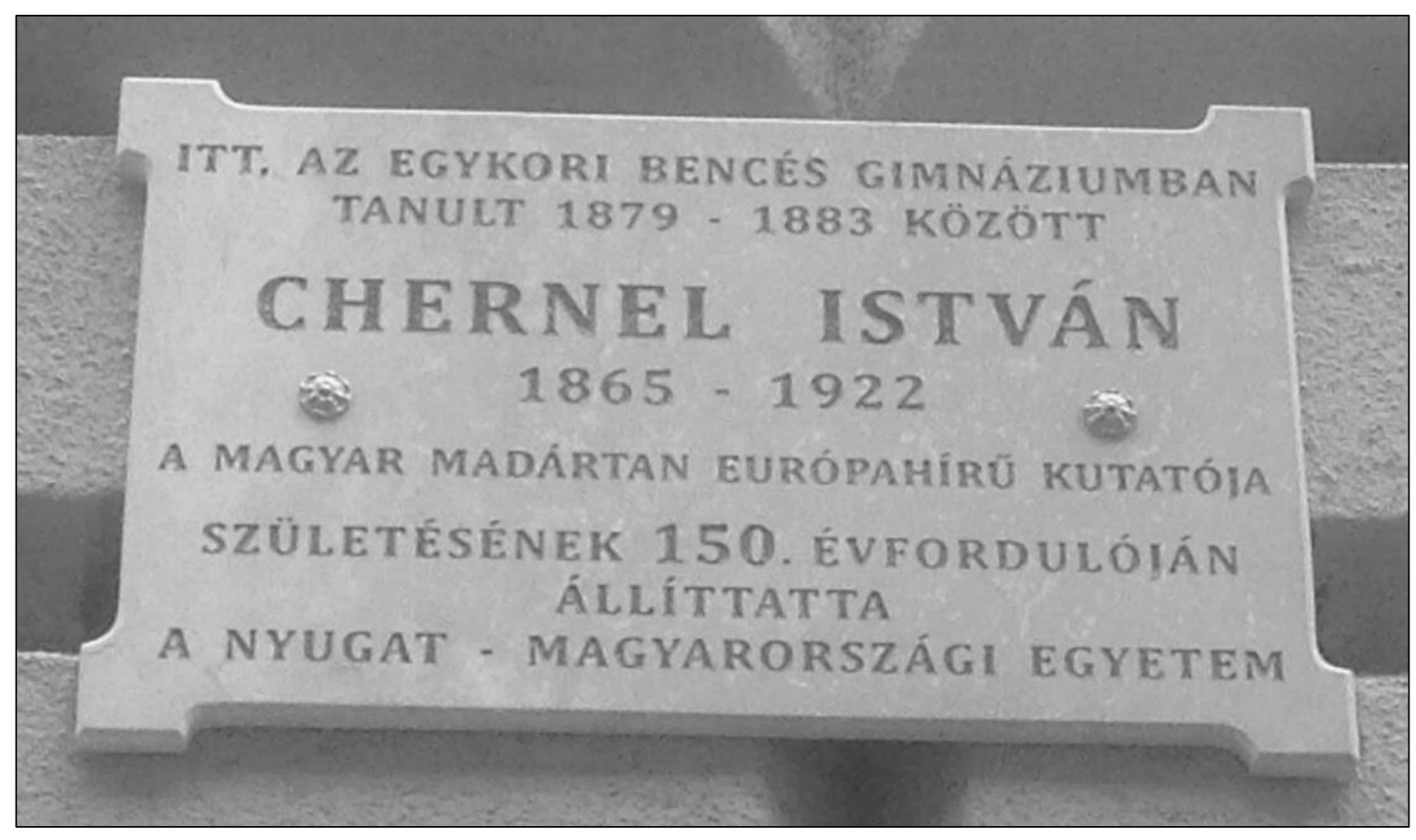

1. ábra: CHERNEL ISTVÁN emléktáblája Sopronban

Figure 1: ISTVÁN CHERNEL's plaque in Sopron

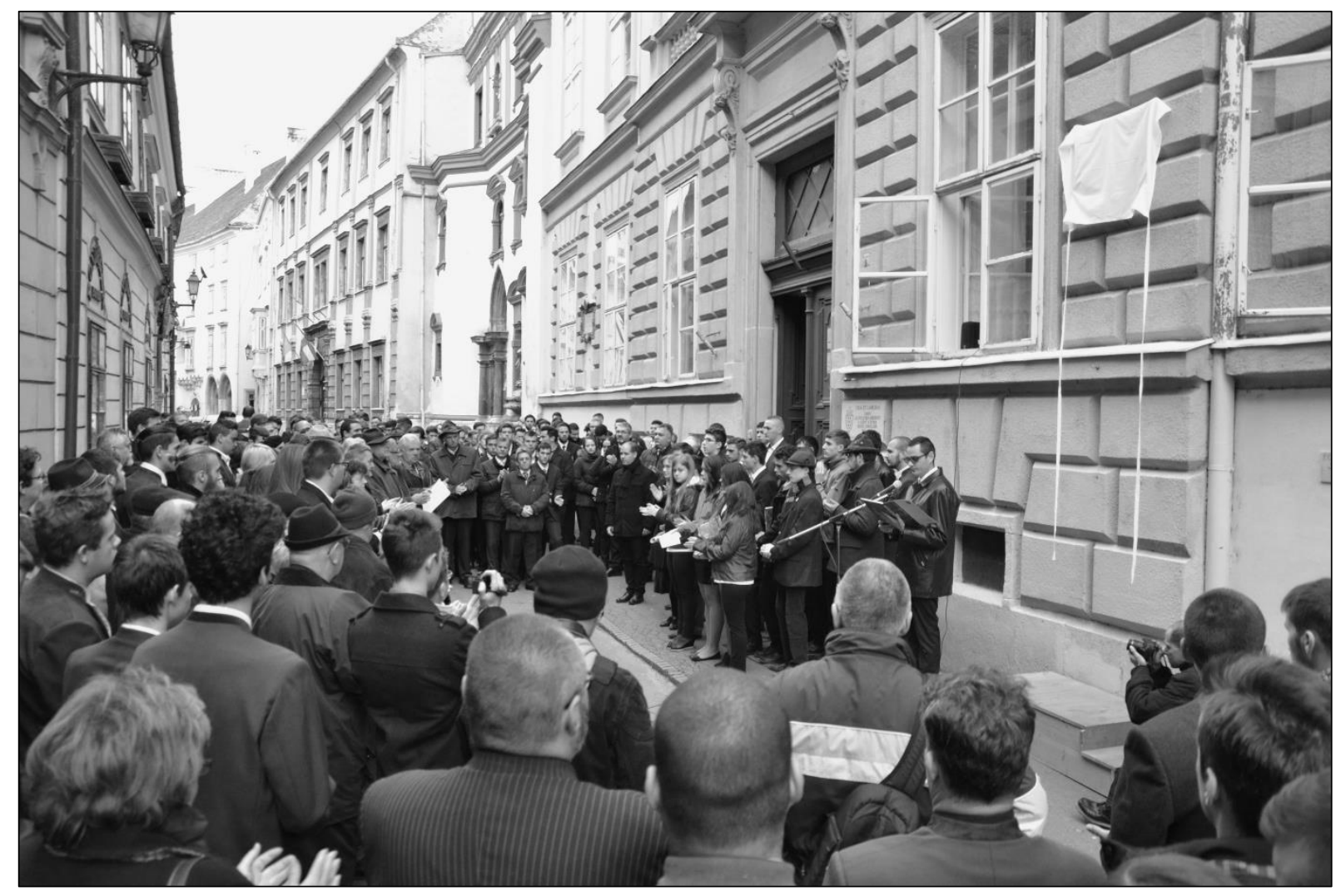

2. ábra: CHERNEL emléktábla avató ünnepség Sopronban, a Szt. György utcában Figure 2: CHERNEL's plaque inauguration ceremony in Szt. György Street, Sopron 


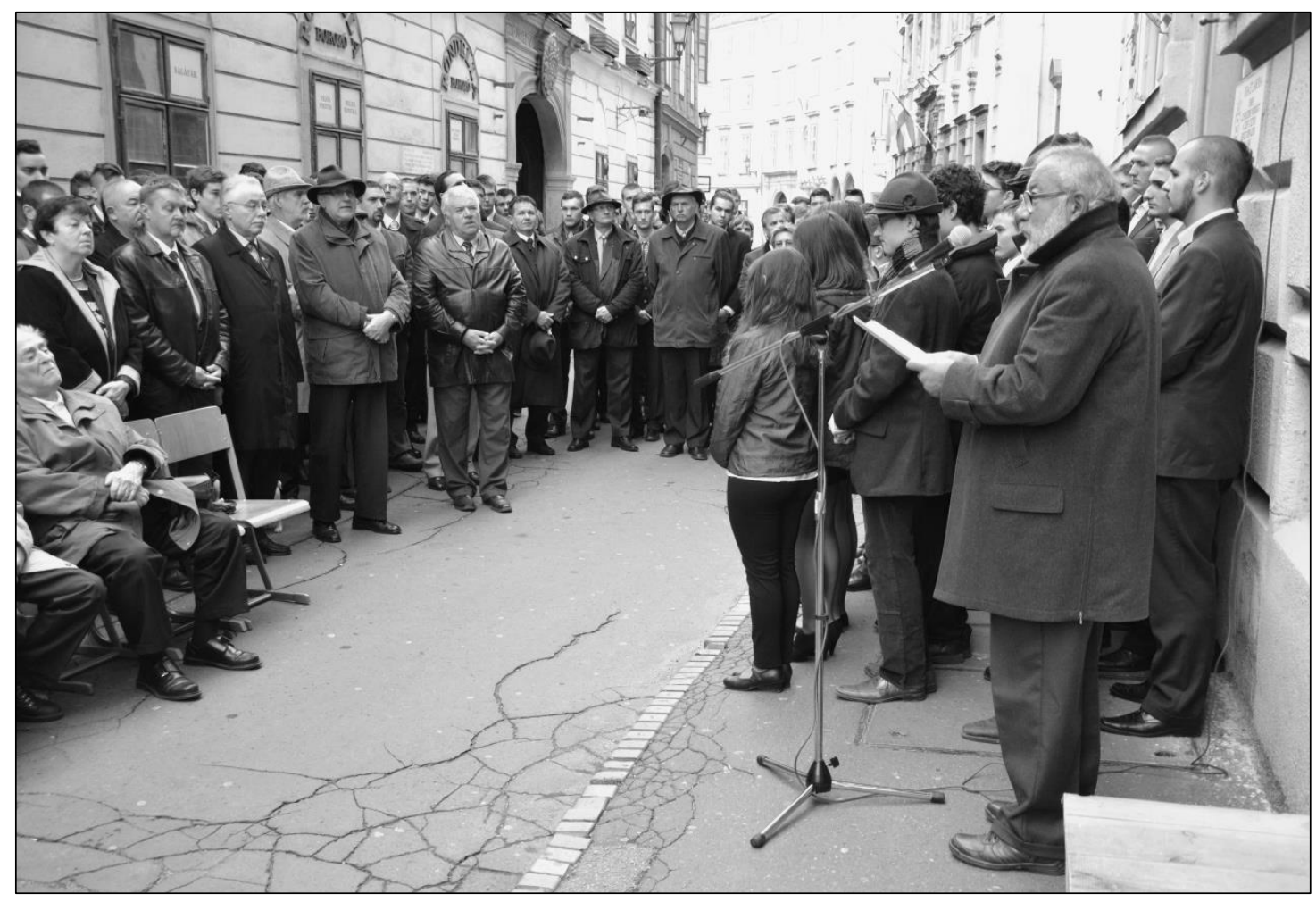

3. ábra: Emléktábla avató beszédét tartja KÁRPÁTI LÁSZLÓ

Figure 3: LÁSZLÓ KÁRPÁTI gives the inaugural speech of the plaque

KÁRPÁTI LÁSZLÓ avatóbeszédét az alábbiakban közöljük:

Tisztelt Polgármester úr! Helyettes államtitkár úr! Rektor úr! Igazgató úr! Kedves Ifjúság! Mélyen tisztelt Hölgyeim és Uraim!

Egy történelmi nevezetességü épület előtt állunk Sopron belvárosában, a Szent György utcában. Ma, a Trianoni diktátum miatt a csonka Hazába menekült Temesvár - Hidasliget Vadászerdői Erdészeti Szakiskola 130 éves jogutódja, a nemzetközi hírü erdész professzorunkról, ROTH GYULÁRóL elnevezett, patinás Erdészeti és Faipari Szakközépiskola müködik itt. De ez az épület adott otthont egykor a Jezsuita Gimnáziumnak - ahol a nagymartoni születésű KITAIBEL PÁL, az egyik legzseniálisabb magyar természettudós tanult 4 évig.

Mint ismert II. JÓZSEF 1782-ben szekularizációs rendeletével felszámolta a szerzetesrendek többségét, de FERENC király 1802-ben újra engedélyezte a rendek müködését, s e nevezetes épület a bencések Szent Asztrikról elnevezett Gimnáziuma lett. Másfél száz évig virágzott ez az intézmény egészen a második világháborút követő kommunista hatalomátvételig, az iskolák államosításáig, 1948-ig. Nagyhírü, tudós tanárok tanítottak itt és a tanítványok közül sokan futottak be sikeres és nevezetes életpályát.

A XIX. sz. végén tanított és tudományos munkát folytatott e falak között a kőszegi születésű FÁSZL ISTVÁN. Az intézmény 1882/1983-as tanévéről szóló Értesítőben jelentette meg Sopron madarairól összeállított monográfiáját, amely az első összefoglaló madártani munka városunk környékéről és a Fertőről. Fejlesztette, gazdagította az iskola természetrajzi gyűjteményét. Több mint ezer madárpreparátumot készített, feldolgozta a város környékének légyfaunáját és virágos növényvilágát is. Utóbbi sajnos nem jelent meg az ő életében, de a kézirat nemrég előkerült a Bencés Rend pannonhalmi irattárából, s ezt a szintén alapmünek számító florisztikai enumerációt FARAGÓ SÁNDOR úr, a NYME rektora segítségével a 
Növénytani és Természetvédelmi Intézet vezetője BARTHA DÉNES professzor úr a közelmúltban megjelentette.

FÁSZL ISTVÁN föleg ornitológus volt. A Magyar Ornithológiai Központ 1893-ban történt létrehozása után rendszeresen küldte jelentéseit a madárvonulásról a Központ vezetőjének, HeRMAN OTTÓNAK. Munkásságára emlékezve a Magyar Ornitológusok Szövetsége - a mai Magyar Madártani és Természetvédelmi Egyesület jogelődje emléktáblát helyezett el az iskola Szent György utcai homlokfalán.

Sajnos élete egyik fő munkája, a természetrajzi gyüjtemény - amit még maga FERENC JÓZSEF királyunk is megtekintett -, a második világháborúban elpusztult. CSAPODY ISTVÁN erdőmérnök-botanikus, a bencés gimnázium egykori diákja így emlékezett meg erről: „1944. dec. 6.-án.. az angolszászok irtózatos szőnyegbombázást zúdítottak Sopronra, aminek következtében a német megszállókkal telizsúfolt belváros nagy része, benne a Bencés Gimnázium is romhalmazzá változott. Elözöleg az utcafronton elhelyezkedö természetrajzi szertárba mindent összehordtunk SzÓLÁS HONOR természetrajz tanárunkkal, hogy biztonságba helyezzük... az értékeket. Éppen ezt a szertárat az egyik bomba telibe találta és megsemmisült. Így hamvadt el FÁSZL ISTVÁN jeles bencés ornitológus preparált madárgyüjteménye és ..a herbárium..."

FÁSZL IsTVÁN tudós munkássága mellett kiváló pedagógus is volt. Természetrajzi, madártani érdeklődése különösen két tanítványára hatott: a szintén kőszegi születésü CHERNEL ISTVÁNRA és a nezsideri CSÖRGEY TITUSZRA, akik később mindketten a magyar madártani jelesei, az Ornitológiai Központ vezetői lettek.

CHERNEL ISTVÁN 150 évvel ezelött, 1865. május 31.-én született törzsökös magyar nemesi családban. Édesapja CHERnEL KÁLMÁN, édesanyja gr. tolnai FESTETICS MÁRIA volt.

Apja érdeklődését a történelem kötötte le, de szívesen foglalkozott a természettudomány különböző ágaival is, s föleg a madarakkal. Az ötéves katonáskodás után 1863-ban fotográfusként Köszegen müködő HERMAN OTTÓ, egy frissen kitömött ugartyúkot ajándékozott neki. Ebből született a barátságuk, s BRASSAI SÁMUEL, az Erdélyi Múzeum Egylet polihisztor igazgatója CHERNEL KÁLMÁN ajánlólevelével vette föl HERMANT konzervátori állásba - saját költségére.

CHERNEL ISTVÁNT gyermekkora óta érdekelték a madarak. A soproni Bencés Gimnáziumban FÁsZL ISTVÁN tanára tanította meg a preparálásra. Vele együtt sokat kirándult a város környékére, a Fertőre és a Hanságba, hogy madártani megfigyeléseket végezhessen. Megfigyeléseit rendszeresen publikálta. Egyik első dolgozata a „Madártani kutatások a Fertő délkeleti részein és a Hanságban" a mai Fertő-Hanság Nemzeti Park madártani értékeinek 130 évvel ezelőtti bemutatásának tekinthető.

1883-ban érettségizett. Önkéntesi évét a 14. Windischgraetz dragonyosoknál szolgálta le Kőszegen. Apja kívánságára jogi tanulmányokat kezdett 1884-ben Pozsonyban. Két éves pozsonyi tartózkodása alatt a Csallóközben és a Kis-Kárpátokban folytatott madártani megfigyeléseket. Ezután Budapesten tanult, $\mathrm{s}$ itt bőséges lehetősége nyílt a Nemzeti Múzeumban és a fővárosi könyvtárakban ornitológiai ismeretei gyarapítására.

1887-ben a Természettudományi Közlönyben közzétette az első magyar ornitológiatörténeti munkát „A honi madártan történetéböl” címmel, 1889-ben pedig a Magyar Könyvszemlében közölte „Bibliographia Ornithologica Hungarica” c. dolgozatát. Ekkor már rendszeresen látogatta későbbi kedvenc kutatási területét a Velencei-tavat.

1887 nyarán Erdélybe látogatott. Enyeden fölkereste CSATHÓ JÁNOST a híres erdélyi ornitológust és összeismerkedett HERMAN OTTÓVAL, aki hívta őt norvégiai tanulmányútra, de nem mehetett jogi tanulmányainak befejezéséig.

Utóbbi 1888-ban történt meg, s még ebben az évben Sopronba került közigazgatási gyakornoknak, ugyanakkor az ornitológiai kutatások iránti törekvését nem adta föl. 1890-ben 
kezdődött a II. Nemzetközi Ornitológiai Kongresszus szervezése Budapesten, s a titkári teendőket CHERNEL ISTVÁN látta el.

1891-ben megnősült. Felesége a Pozsonyban megismert ROTH DÓRA lett. Házasságukból két gyermek született: MÁRTA és MIKLÓs. Fia az első világháborúban hősi halált halt.

Chernel István 1898-ban jelentette meg a Magyar Birodalom madarainak névjegyzékét FRIVALDSZKY JÁNOS feldolgozásával, magyar és latin nevekkel. Főműve viszont 1899-ben jelent meg 2 vaskos kötetben „Magyarország madarai, különös tekintettel gazdasági jelentöségökre" címmel. A hatalmas ismeretanyagot tartalmazó munka bemutatta az összes hazai madárfajt, részletesen tárgyalva küllemüket, hangjukat, életmódjukat és gazdasági jelentőségüket. Ilyen átfogó munka CHERNEL könyve után majd egy évszázadig,1984-ig nem jelent meg Hazánkban. A könyv jelentőségére és bőséges információtartalmára már „A szerző megnyitója" c. bevezetőböl is következtethetünk:

„....megkezdtem kirándulásaimat is az ország madártanilag is legnevezetesebb vidékeire. Hosszabb idöt töltöttem 1887-ben a Velenczei tavon, melynek rendkívül érdekes és gazdag madárfaunáját azóta is minden évben, tavaszszal és öszszel, hónapokon, vagy legalább is heteken át tanulmányozta. Itt vetettem meg madárgyüjteményemet is, mely - noha pár száz példány a Nemzeti Múzeumba került-jelenleg 1500 darabot számlál.

A Velenczei tó után sorba kerültek - még pedig ismételten - Erdély, a Balaton, Fertö és Hanyság, majd a dunántúli megyék, a Kis-Kárpátok, a Duna felsövidéke, később az Alduna, a deliblati homoksivatag, a borsodi „Bükkhegység”, a Tiszamente Heves megyében, a magyar tengerpart stb. Meglátogattam nevezetesebb madárgyüjteményeinket...

A hazában végzett kirándulásaim közben szorgalmasan jegyeztem nemcsak a nép ajkán élö különbözö madárneveket, hanem kikérdeztem a népnek azt a romlatlan nyelvü és eredeti észjárású rétegét, mely bizonyos ösi elemeket megőrizve... legbövebben bugyogtathatta azokat a forrásokat, melyekből a madárvilág és a magyarság viszonyának megértését merithettem.

De egyidejüleg még egy fontos teendöm akadt: ... a fajok gazdasági jelentöségének megvilágítását a meglévő adatok és irodalom nyomán csak hiányosan tehettem volna, mert a döntö ebben a madarak táplálkozása. Ezt illetö vizsgálataim pedig több tekintetben hézagosak voltak. E czélból az ország lehetöleg sok különbözö pontjáról, különbözö idöszakból, különbözö nemü és korú példányoktól származó, azonkívül egy-egy fajból nagyobb számú madárbegy - és gyomortartalmakat gyüjtöttem.

És még egy... ez a madárfajok mértéke volt, melyre nézve irodalmunkban... semmis sem állott rendelkezésemre... Szintúgy végezni kellett a tojások megmérését is, még pedig tisztán magyar példányok és fészekaljak nyomán."

A híres szakkönyv megjelenése után fontos munkák következtek még. 1904-ben lefordította BREHM Tierleben „Az állatok világa” c. művének három, madarakkal foglalkozó kötetét és a hazai ismeretanyaggal bővítette. Nemzetközi elismertségét bizonyítja, hogy felkérték a híres német ornitológus NAUMANN 12 kötetes Közép-Európa madarait bemutató könyvsorozatában való közremüködésre.

A tudományos tevékenység mellett kiemelkedő gyakorlati madárvédelmi munkát is végzett. Kőszegi kertjében mesterséges madárodú és madáretető mintatelepet alakított ki. Részt vett a budapesti, berlini, párizsi és torinói madárvédelmi kongresszusokon is. 1902-ben ő szervezte az első „Madarak és fák napját” Köszegen. Szükebb hazájában Vas vármegyében megalapította a Vasvármegyei Múzeum Természetrajzi Tárát, amelynek őri feladatait 4 éven keresztül ellátta.

HERMAN OTTÓ halála után két évvel, 1916-ban kinevezték az Ornithológiai Központ tiszteletbeli igazgatójának - miniszteri tanácsos ranggal. Nem kívánta Kőszeget elhagyni, 
ezért a gyakorlati munka egy részét CSÖRGEY TITUSZ helyettesére bízta. Szerkesztette a Központ, majd Magyar Királyi Madártani Intézet évkönyvét az Aquilát és szervezte a madármegfigyelő hálózatot.

CHERNEL ISTVÁN sokoldalú, mondhatni reneszánsz ember volt. Munkája mellett festett, verseket írt, muzsikált, énekelt és sportolt. Norvégiában ismerkedett meg a síeléssel, amit igyekezett hazánkban is meghonosítani. 1892-ben elsőként sízett Kőszegen feleségével, aki az első női síző volt hazánkban. A sízésröl egy kis könyvet is írt, megteremtvén a sportág szaknyelvének magyar alapjait.

Az első világháború borzalmai, a forradalmak, a kommün káosza, hiába hazavárt, szeretett fia elvesztése lelkileg súlyosan érintették. Budapestre utaztában megfázott a fütetlen vonaton és öt is elsodorta a végzetes spanyolnátha 1922 telén 57 éves korában.

CHERNEL ISTVÁN gyermekkorától kezdve naplót írt. A Pannonhalmi Bencések levéltárában fönnmaradt naplóinak anyagát, amelyeket az Alpok-alja kutatását szervező, kiváló paleobotanikus, HORVÁTH ERNÖ filmtekercseken is őrzött, FARAGÓ SÁNDOR dolgozta fel, egészítette ki és két kötetben ez évben CHERNEL ISTVÁN születésének 150-edik évfordulója tiszteletére „Lélekkel teljesitett hívatás” címmel kiadta. E könyvekböl, naplósorokból megismerhetjük a Gondviselésben bízó, a magyar Hazához mindenkor hü, érzelemgazdag CHERNEL ISTVÁNT, akit soproni diákéveitől kezdve áthatott a bencés szellem, Szent Benedek regulája szerint élő tanárai, különösen FÁSZL IsTVÁN kisugárzása, az „Ora et labora!" jelmondat, ami utal arra a többletre, amit a bencés elitképzés máig megvalósít.

A most avatandó emléktábla - amit KÁROLYI GYULA kőfaragómesternek és Családjának köszönhetünk - szolgáljon figyelmeztetöül és útmutatásul az itt járó erdész diákoknak:

Tanuljatok! Tudjatok! Legyetek jó és sikeres Magyarok! Ti soproni Polgárok pedig legyetek büszkék városotok történelmi iskoláira, s az itt végzett, nemzetközi hírü tudóssá növekedett diákokra!

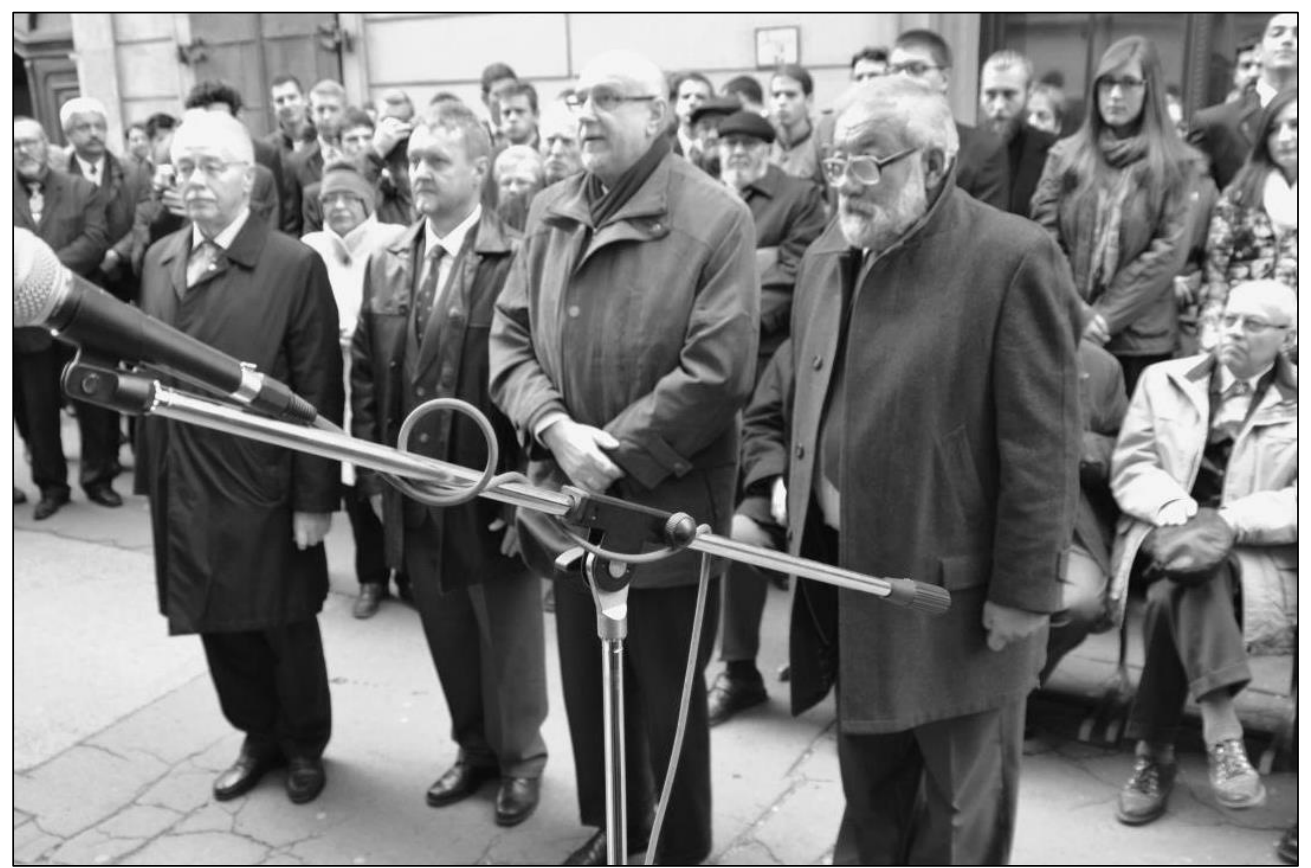

4. ábra: Az emléktábla megkoszorúzása: FODOR TAMÁs polgármester, HOCZEK LÁSZLÓ igazgató, FARAGó SÁNDOR rektor, KÁRPÁTI LÁSZLÓ ny. igazgató

Figure 4: Wreathing of the plaque: TAMÁS FODOR mayor of City Sopron, LÁSZLÓ HOCZEK director of the Roth Vocational Secondary School, SÁNDOR FARAGÓ rector of the University of West Hungary, LÁSZLÓ KÁRPÁTI retired director of the Fertö-Hanság National Park 